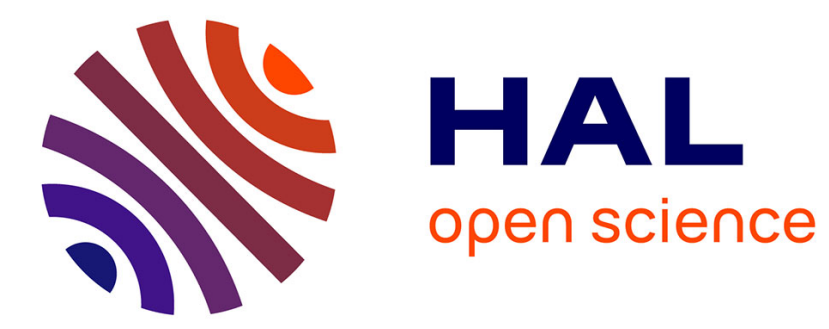

\title{
Argument demotion in Japhug Rgyalrong
}

Guillaume Jacques

\section{To cite this version:}

Guillaume Jacques. Argument demotion in Japhug Rgyalrong. Haude, Katharina and Authier, Gilles. Ergativity, Valency and Voice, Berlin: Mouton De Gruyter, pp.199-225, 2012. halshs-00677809

\section{HAL Id: halshs-00677809 \\ https://shs.hal.science/halshs-00677809}

Submitted on 9 Mar 2012

HAL is a multi-disciplinary open access archive for the deposit and dissemination of scientific research documents, whether they are published or not. The documents may come from teaching and research institutions in France or abroad, or from public or private research centers.
L'archive ouverte pluridisciplinaire HAL, est destinée au dépôt et à la diffusion de documents scientifiques de niveau recherche, publiés ou non, émanant des établissements d'enseignement et de recherche français ou étrangers, des laboratoires publics ou privés. 


\section{Argument demotion in Japhug Rgyalrong}

\section{Guillaume Jacques}

\section{Introduction 1}

Japhug (Chabao in Chinese), a Sino-Tibetan language spoken in China (Mbarkhams county, Rngaba autonomous region, Sichuan Province), is unusual among the languages of this family in displaying complex verbal morphology. Alongside Tshobdun (Caodeng in Chinese), Zbu (also known as Showu, Ribu or Rdzongmbur) and Situ (Eastern Rgyalrong), it belongs to the so-called Rgyalrong languages. ${ }^{2}$

Like some other Sino-Tibetan languages of Sichuan, Japhug has an ergative case marking system and a verb agreement system which indexes two arguments (for transitive verbs) following a hierarchical pattern. No ergative syntactic pivots are found in nominalization, complementation or equi-NP deletion constructions.

This paper is divided into seven parts. First, we will discuss the morphological and syntactic marking of transitivity in Japhug, the basis for any study of transitivity-changing devices in this language. Second, we will describe the generic argument marking system, which, like nominal case marking, shows ergative alignment. Third, passive and anticausative forms will be considered. These forms have a fairly restricted range of uses, since "generic" forms are employed in most cases where the passive would be found in European languages. Fourth, we will analyse the two antipassive prefixes found in Japhug, which are not productive, but have the interesting property of distinguishing between human and non-human suppressed patients. Fifth, we will briefly describe the de-experiencer prefix, which can derive an intransitive verb from a transitive verb of perception. Sixth, we will discuss the labile verbs, a small class of verbs which can be either transitive or intransitive without any derivational marking; these verbs are uniformly agent-preserving and never patient-preserving. Finally, we will present incorporation, the last morphological means of suppressing the patient in Japhug. 
$2^{\perp} \circ$ Error! Style not defined.

\section{Transitivity marking in Japhug}

Transitivity is an essential feature of the Japhug verbal system. There is never any ambiguity about whether a given verb is transitive or not. A complete account of person agreement and TAM markers in Japhug is beyond the scope of the present article, but in this section all affixes relevant to the marking of transitivity will be discussed.

\subsection{Morphological transitivity}

In Japhug, transitive verbs regularly agree with two arguments, so that many transitive verbal forms (such as $1>2$, i.e. first person agent and second person patient) have no equivalent in intransitive verbs.

However, third person patient forms $(1>3,2>3$ and $3>3)$ are in some cases almost indistinguishable from intransitive verbal forms. Two of the markers which are found exclusively with transitive verbs are restricted to a phonologically conditioned subset of these verbs: the regular stem 3 formation, ${ }^{3}$ which only occurs with verbs whose basic stem ends in $-a,-u,-$ $o$ and $-u$, and the $-t 1 \mathrm{SG}>3 / 2 \mathrm{SG}>3$ past tense suffix, which only applies to open syllable roots.

Fortunately, two morphological tests can be applied to any verb to determine whether it is transitive or intransitive, even if this verb only allows third person patients and has a closed syllable stem. Verbs which possess a stem 3 and make use of the $-t$ past tense suffix always confirm their transitive nature in these two tests as well.

Firstly, transitive verbs take the prefix $a$ - in direct aorist $3>3$ forms. Compare the following examples:

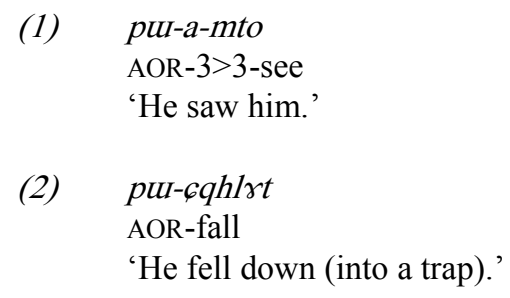

In the first example, the verb is transitive, and the a-prefix appears after the directional prefix pu- which marks the aorist, whereas in example (2) the verb is intransitive and no such prefix appears. 
Secondly, the nominalized forms of transitive and intransitive verbs are distinct: intransitives build their S-nominalization by means of a prefix $k u r$, while for transitive verbs the A-nominalized form makes use of the same $k u$ - prefix (see example 3) preceded by a possessive prefix coreferent with the O. For instance:

\section{(3) u-ku-mto}

3SG.POSS-NMLZ:S/A-see

'The one who sees him'

In example (3), the nominalized form is marked with a third person singular possessive prefix $u$ - indicating the O. Compare this form with (4):

\section{(4) $\mathrm{ku}-\mathrm{Si}$ \\ NMLZ:S/A-die \\ 'The dead one'}

In this example, no such possessive prefix appears. Thus, on the basis of the direct aorist $3>3$ form and the nominalization in $k u r$, it is always possible to determine whether a given verb is transitive or not.

The strict morphological transitivity marking found in Japhug and other Rgyalrong languages is relatively rare among Sino-Tibetan languages, where transitivity is often difficult to define (as for example in Chinese or Tibetan). However, Rgyalrong languages are not the only ones in this family to show transitivity marking: Dulong/Rawang languages (LaPolla 2001:284) and Kiranti languages also have a fully-fledged set of transitivity-marking affixes on the verb.

\subsection{Case marking}

The formal distinction between transitive and intransitive verbs is not limited to their morphology. Japhug has a simple case marking system, which presents ergative alignment: A arguments are marked with the enclitic $k u,{ }^{4}$ while $\mathrm{S}$ and $\mathrm{O}$ are left unmarked, as can be seen in sentences (5) and (6):
(5) $\quad$ sdrrzi
ku tamu pu-a-mto
Rdorje ERG Lhamo AOR-3>3-see
'Rdorje saw Lhamo.' 
$4^{\perp} \circ$ Error! Style not defined.

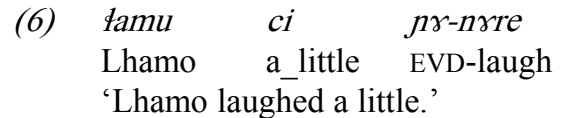

When both participants are overt, it is therefore possible to determine whether the verb is transitive or intransitive on the basis of case marking. Ergative marking is obligatory with third person participants in Japhug for all TAM categories, but only rarely appears with SAP pronouns such as azo 'I' and nrzo 'you'.

With intransitive verbs, the ergative case can sometimes be used, but it conveys a specific comparative meaning:

\section{(7) nґъо ku jui-tul-cha \\ you ERG CONST-2-be_capable}

'You are more capable.'

Word order is verb-final, the agent usually preceding the patient. Sentences with an overt agent and patient are fairly rare in actual texts. As in many polysynthetic languages with indexation of two arguments, it is quite common to omit both agent and patient NPs (Mithun 1999:190-193): the only necessary element of a sentence is the finite verbal form. Covert arguments are normally definite. A minimal sentence such as:

\section{(8) to-ndza \\ EVD-eat \\ 'He ate it.'}

can only appear if both the eater and the thing eaten have been mentioned before or are implicit. Therefore, unlike in European languages such as French or English, omission of the $\mathrm{O}$ argument is not available as a potential means of expressing an indefinite patient. Other morphological devices, such as antipassive, generic or incorporation constructions, are required to serve that purpose.

\subsection{Ditransitive verbs}

In ditransitive verbs involving a recipient, such as 'give' or 'tell', we observe in Japhug both indirective and secundative alignment (Haspelmath 
2005). No more than two arguments may be indexed on the verb, and the nature of the second argument indexed (recipient or theme) is lexically determined for each verb. This can be illustrated with two verbs meaning 'give', mbi and kho.

The first of these, $m b i$, encodes the recipient as its second argument (Haspelmath's secundative alignment):

(9) $\begin{array}{ll}k i & \text { nul-ta-mbi } \\ \text { DEM } & \text { IPFV-1>2-give }\end{array}$

'I give this to you.' (Gesar, 197)

Meanwhile, the verb kho allots the theme to the second argument position, and the recipient can only be marked as an external argument taking the dative suffix $-\varsigma k i$ or - phe (indirective alignment): 5

(10) $a-m e$

$$
\begin{array}{lll}
\text { a-me } & \text { nuu-khám-a } & \text { pu } \\
\text { 1SG.POSS-daughter } & \text { IPFV-give[3]-1SG } & \text { N.PST:be }
\end{array}
$$

'I will give (you) my daughter.' (The Frog, 78)

The alignment of ditransitive verbs in Japhug is quite strict, and no verb can be both indirective and secundative.

\subsection{Semi-transitive verbs}

Some two-place verbs in Japhug are distinctive in that they neither present transitivity markers nor require ergative marking on the agent. This class of 'semi-transitive' verbs includes verbs of motion and some verbs of perception. We provide some examples to illustrate this intriguing phenomenon:

$\begin{array}{llll}\text { (11) } & \text { nut } \quad \text { ra } \quad c-k \gamma-r u & j \gamma \gamma \\ \text { DEM PL } & \text { TRANS-IMP:EAST-look } & \text { N.PST:could } \\ \text { 'Just go to see them.' (Smanmi, 110) } & \end{array}$

In this example, the verb $r u$ 'look at' clearly has two distinct arguments, but it fails to show any transitive marking. If it were a normal transitive verb, the verb form seen in (11) - along with all other non-past, imperfective and imperative forms - would make use of the special 'stem 3' mentioned above, involving the vowel alternation $u \rightarrow e$. Meanwhile, other perception 
$6^{\perp} \circ$ Error! Style not defined.

verbs such as mto 'see' are fully transitive: the person seeing receives ergative marking and both arguments are indexed on the verb.

Like the verb 'look at', motion verbs are intransitive, although they might be considered to have two arguments: the person/animal moving and the place travelled towards (the latter is not usually marked with an oblique case in Japhug). This class includes the verb ce (Aorist stem ari ' 'go'.

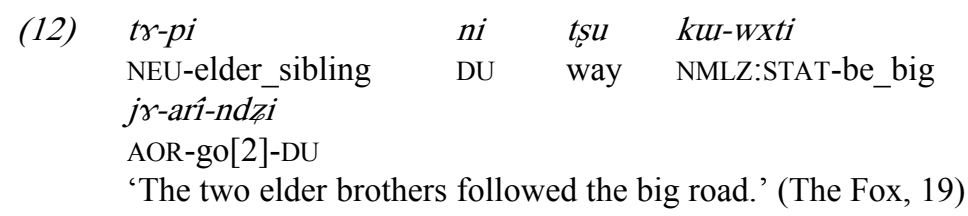

This phenomenon is illustrated here in example (12), where the persons going (the elder brothers) do not receive ergative case. Other tests for transitivity (nominalization, transitivity affixes on the aorist, etc.) would also fail.

Interestingly, Dulong/Rawang, the other sub-branch of Sino-Tibetan to share the strict transitivity marking seen in the Rgyalrong languages, also possesses a class of 'semi-transitive' verbs, whose members overlap with those in Rgyalrong: in particular, perception and motion verbs are again found to display this behaviour (LaPolla 2008).

\section{Generic marking}

As mentioned in the introduction, Japhug and other Rgyalrong languages have a direct/inverse marking system (DeLancey 1981, Sun and Shi 2002). The inverse marker $w \gamma^{-}$appears on verb forms where the agent is third person and the patient is SAP, or when the agent is non-human and the patient human, for instance:

\section{(13) tha a-mr-pu-tú-Wy-sat \\ otherwise IRR-NEG-PFV-2-INV-kill \\ 'Otherwise she would kill you.' (Nyima vodzer, 36)}

The use of the inverse in Japhug has been described in Jacques (2010a), so this topic will not be discussed in detail here. It should be noted, however, that unlike passive and antipassive prefixes this affix does not 
cause a change in valency: the verb remains transitive (the inverse marker cannot appear on an intransitive verb) and both arguments can be marked in the verb morphology.

A special use of the inverse prefix $w y$ - is nevertheless highly relevant to the topic covered in this paper: namely what I will call its "generic" use, a function cross-linguistically associated with passive forms. No other language with direction marking seems to share this feature, as can be seen from Zúñiga's (2006) recent survey of direct/inverse systems in languages of the New World. Japhug generic forms often appear in sentences expressing general truths, and generic marking is extremely common in procedural texts:

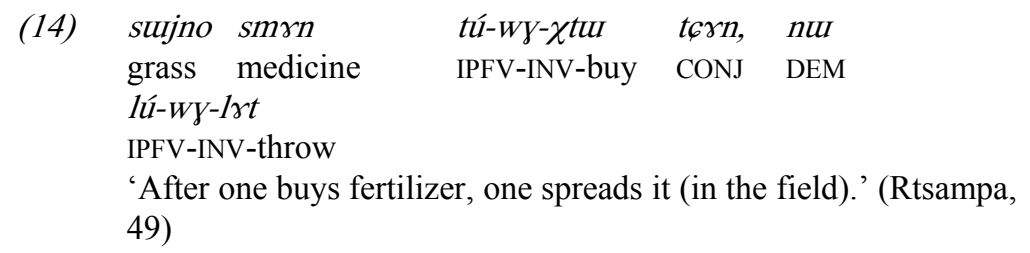

The generic form can be strictly distinguished from the normal inverse. Inverse verbal forms imply that the agent is lower or equal to the patient on the Empathy Hierarchy. Inverse marking is obligatory if an inanimate agent acts upon a human, and conversely, it can never appear when a human acts upon an inanimate. This effect of the Empathy Hierarchy does not apply to generic forms. As example (14) shows, the generic inverse can be used with a (generic) human agent and an inanimate patient. It never takes dual or plural suffixes. This implies that generic arguments, even humans, are lower on the empathy hierarchy than inanimates. The following hierarchy should thus be postulated:

\section{(15) SAP $>$ human $>$ animal $>$ inanimate $>$ generic argument}

Non-generic inverse forms differ from generic ones in two ways. Firstly, they can take number suffixes, and secondly, they cannot appear if the patient is inanimate. Consider the following example:

\begin{tabular}{|c|c|c|c|}
\hline (16) & зируо & $u-\operatorname{ta} s$ & $p u ́-W \gamma-t a-n d z i$ \\
\hline & $\begin{array}{l}\text { stake } \\
n d z i-p a\end{array}$ & $\begin{array}{r}\text { 3SG.POSS-on } \\
\text { smi }\end{array}$ & 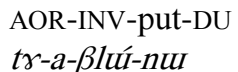 \\
\hline
\end{tabular}


$8^{\perp} \circ$ Error! Style not defined.

\author{
2DU.POSS-underfire AOR-3 $>3$-burn-PL CONJ \\ tr-pi впавna zo pú-wy-sat-ndzi \\ NEU-elder brother both ADV AOR-INV-kill-DU \\ ju- $\eta$ u. \\ IPFV-be \\ 'People put the two of them on the stake, lit the fire under them, \\ and killed both of them, the two brothers.' (The Fox 180-181)
}

All three verbs in (16) share the same agents (unspecified in the story, but probably the king's servants or the villagers). The first and the third have inverse marking (and agree in number - dual - with their patient), while the second is direct, with plural agent marking because its patient is inanimate (the fire, smi). The absence of an inverse form on this verb confirms the fact that the inverses in the first and the second are not generic, for otherwise we would expect the second verb to be in the inverse form too. In (16), the inverse can be used because both the agents and the patients are human, and thus equal in terms of the Empathy Hierarchy. ${ }^{6}$

The inverse prefix is only used when the generic argument is the agent of a transitive verb. For intransitive verbs or patients, a different affix is used: the $k u-$ prefix. This prefix is homophonous with the nominalizer described in section 2, but is unrelated to it at least synchronically. The uses of this prefix are exemplified in sentences (17), from a story about the yeti, and (18), from a procedural text:

\begin{tabular}{|c|c|c|c|c|}
\hline \multirow[t]{6}{*}{ (17) } & $u-B r r i$ & $n \gamma$ & UI-вみri & $\not \circ O$ \\
\hline & \multirow{2}{*}{$\begin{array}{l}\text { 3SG.POSS-front } \\
\text { ju-ku-phyo }\end{array}$} & CONJ & 3SG.POSS-front & $\mathrm{ADV}$ \\
\hline & & & a-pu- $\eta u$ & tce, \\
\hline & \multicolumn{2}{|c|}{ IPFV-GENR:S/O-flee } & IRR-IPFV-be & CONJ \\
\hline & maka $\quad$ ६o & \multicolumn{2}{|c|}{ mu-pjr-ku-mto } & khi \\
\hline & at_all & \multicolumn{2}{|c|}{ NEG-EVD-GENR:S/O-see } & HEARSAY \\
\hline
\end{tabular}

In this example, both the first verb, 'flee' (intransitive), and the second, 'see' (transitive), have the generic prefix kut. In the second verb, the generic argument is not the $\mathrm{A}$ (the one who sees) but rather the $\mathrm{O}$ (the one seen), as the $\mathrm{A}$ is definite (the yeti).

The generic forms are compatible with both imperfective and aorist forms, as shown in the following example. Imperfective forms are the most 


\section{$10^{\perp} \circ$ Error! Style not defined.}

This is one of the few contexts in Japhug where ergativity is present, other than in case marking. In other syntactic structures, no ergative alignment is found: nominalization patterns in Rgyalrong languages follow accusative alignment (Sun 2003:497), and equi-NP deletion shows no syntactic pivot (Jacques 2010a).

Japhug generic forms differ markedly from those described in Tshobdun (Sun 2005), where the inverse is not used in this function and a strict distinction is observed between human and non-human generic forms.

Unlike in Kryz, where the passive form conveys deontic/habitual meaning (Authier, this volume §4.1), in Japhug such contexts instead make use of the generic form, and the passive, as we will show, never bears this kind of meaning.

\section{Passive}

Japhug has two agentless passive forms, which present complex morphophonological alternations. These alternations have been described in Jacques and Chen (2007), and we will concentrate our discussion here on the functions of these forms. Unlike the generic described above, the passive belongs to the domain of derivational morphology, and changes the valency of the target verb, which becomes intransitive.

\section{1. a- passive prefix}

The first passive form, marked by the prefix a- (see Table 1), is fully productive. It has three allomorphs, $a-, \gamma$ - or $k \gamma$-, depending on the preceding prefix (Jacques and Chen 2007). Most transitive verbs can be prefixed with this element, and the resulting intransitive verb cannot have an overt agent.

Table 1: Examples of passive forms

\begin{tabular}{llll}
\hline basic verb & meaning & derived verb & meaning \\
\hline ta & put & $a-t a$ & be put \\
prrt & cut & $a-p r r t$ & be cut \\
$r k u$ & put in & $a-r k u$ & be put in \\
\hline
\end{tabular}

删除的内容 $[\mathrm{A}]$ ：mto

删除的内容 [A]：mto

删除的内容 $[A]$ ： see

删除的内容 [A]： seen 
In the imperfective, past imperfective and past evidential forms, passives have a stative meaning, though a passive interpretation is also possible:

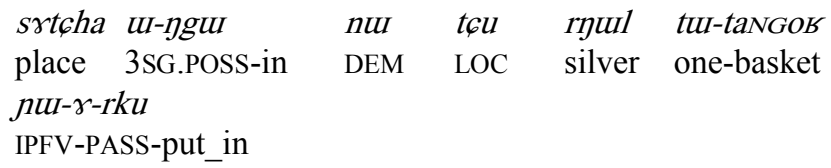

'In that place, there is/someone has put a basket of silver.' (The Divination, 68)

(21) tcheme nut ci thus-sta ri, girl DET a little AOR-wake_up CONJ ut-mphus thrcu nu pul-a-ta 3SG.POSS-buttocks downstream DEM PST.IPFV-PASS-put cti N.PST:be.affirmative 'The girl woke up, and it (the horse embryo) was there / someone had put it under her bottom.' (The Three Sisters, 106)

(22) ul-phungut teu qaputum ci 3SG.POSS-bosom DEM LOC pebble one na-rku juu-nu "tcetha qhuj tce AOR:3>3-put_inIPFV-be a_while this_evening CONJ ki a-phüugu - a-rku- tce this 1SG.POSS-bosom N.PST:PASS-put_in CONJ tcetha pu-mto-t-a zo tce, rfrlpu a_while AOR-see-PST-1SG ADV CONJ king ul-phe tu-ti-a nutra"

3SG.POSS-DAT IPFV-say-1SG IPFV-have to

He put a pebble in his bosom, thinking: "This evening, it will be in my bosom, and as I see it, I will certainly tell (the story) to the king." (Kunbzang, 279)

No overt agent can appear in the same clause, but this is not to say that the passive is forbidden when the agent is known. For instance, in one text we find the following sentence:

puI-a-qrut

tce,

uI-1guu

nut tou 
$12^{\perp} \circ$ Error! Style not defined.

\begin{tabular}{|c|c|c|}
\hline one-piece & $>3$-tear & 3SG.POSS-in \\
\hline rрul qһовqһов & tul-rdos & 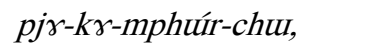 \\
\hline silver ingot & one-piece & IPFV.EVD-PASS-wrap-EVD \\
\hline
\end{tabular}

Although not formally expressed in sentence (23), the agent who put the silver ingots in the bread is known. A few sentences earlier in the same story, we read:
ryul qhовqһов
tul-rdos
ntsur ko-mphur
silver ingot one-piece always EVD-wrap
'She (a character named Lhamo) put a silver ingot in each (piece of bread).' (The Raven, 109)

In the aorist, passive forms do not always have resultative meaning (unlike in Kryz: Authier, this volume 3.2):

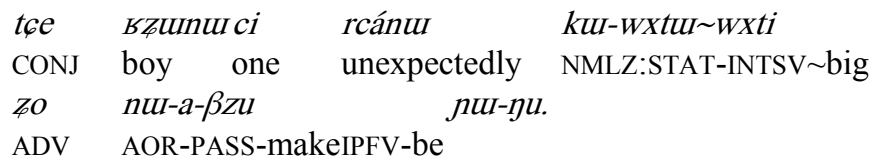

'Then the fox changed into a big boy.' (The Fox, 193)

The $a$ - passive is rare in narratives and also in procedural texts, where generic verb forms are generally used in clauses with a generic agent. It is not commonly used to express situations where the agent is unknown: more usual is inverse (or plural direct) marking on the verb, as was seen in the previous section.

Additionally, on occasion a passive form can display an idiosyncratic meaning which has evolved independently from that of the base verb. This phenomenon is exemplified by a pair of very common verbs in Japhug. The verb pa originally meant 'do' in proto-Rgyalrong, but in this meaning it was supplanted by the Tibetan loanword $\beta z u$ and was preserved only in its secondary meaning, 'close'. However, the corresponding passive form a-pa, originally meaning 'be made', did not come to mean 'be closed'; instead, it independently developed the meaning 'become, change', and thus pa and apa are no longer related synchronically.

A prefix related to the $a$-passive is the $s \gamma$-prefix, which represents the fusion of the causative sul- and the passive a-. Verbs with this prefix are 
few in number, and the situation is quite confused due to the fact that two other homophonous $s \gamma$ - prefixes exist in Japhug, one of which is an antipassive marker (cf. the following section). The combination of passive and causative generates the special meaning 'ask sb to'. For instance, from the verb $m b i$ 'give'7 one derives $s \gamma-m b i$ 'ask sb for sth', in other words 'cause sb to give sth to oneself'.

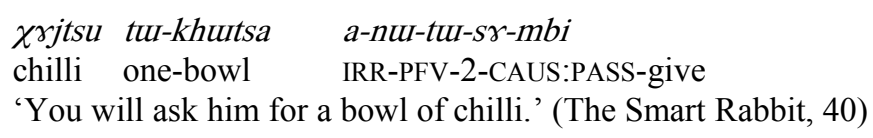

Up to this point, we have taken for granted that $a$ - is to be considered a real passive formant. We wish to dispel any suspicion that this might not be the case. Keenan and Dryer (2007) warn against confusing the passive with other constructions such as middle (p.352), unspecified subject (p.354), inverse (p.356) and antipassive (p.359). However, we know that Japhug has separate forms for generic reference (section 3), inverse (Jacques 2010a) and antipassive (section 5), all of which are entirely distinct from the aprefix. Therefore, the main issue to be discussed is whether the $a$-form is a genuine passive or should be seen as expressing middle voice.

Cross-linguistically, the term 'middle' is used for various verbal forms which generally cover a wide functional range, such as passives, reciprocals, reflexives, autobenefactives, and forms to denote actions affecting an object possessed by the agent. The presence of middle marking has been reported for several Sino-Tibetan languages, such as Rawang (LaPolla 2001). Therefore, the presence of a typologically similar grammatical category in Japhug would not be surprising.

However, it seems clear that the $a$-prefix has a much more restricted range of functions than we would expect if it were a middle marker. In particular, the $a$ - passive never has reflexive meaning: reflexive forms are regularly made from transitive verbs by adding the prefix $\not \zeta \gamma$ - (e.g. sat 'kill', $z_{\gamma} \gamma^{-}$-sat 'commit suicide'). ${ }^{8}$ However, it is possible that in an earlier stage of the language, the $a$ - prefix had a broader range of uses than merely the agentless passive.

One productive verbal form which is historically related to the passive is the reciprocal (see Table 2). It is produced by adding the $a$ - prefix and reduplicating the last syllable of the verb stem. A minority of reciprocal verbs show no stem reduplication, but instead add the double prefix $a-m u-$. All reciprocal verbs are morphologically intransitive. 
$14^{\perp} \circ$ Error! Style not defined.

Table 2: Examples of reciprocal forms

\begin{tabular}{|c|c|c|c|}
\hline basic verb & meaning & derived verb & meaning \\
\hline$n d z a$ & eat & $a-n d z u-n d z a$ & eat each other \\
\hline nurutsa & envy & a-nurutsutsu-tsa & envy each other \\
\hline $1 \gamma t$ & throw & $a-1 u-1 \gamma t$ & fight each other \\
\hline mto & see & a-mu-mto & see each other \\
\hline$t i$ & say & $a-m u-t i$ & tell each other \\
\hline
\end{tabular}

The reciprocal form in $a$-is obviously related to the $a$-passive, and this could challenge our claim that the prefix $a$ - is a real passive formant. However, the relationship between the passive and the reciprocal is purely historical, and is not synchronically valid in modern Japhug.

The common ancestor of the passive formant $a$ - and the $a$ - element seen

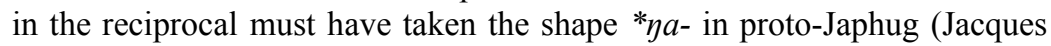
and Chen 2007:889). This *ya- prefix must have functioned as a much broader intransitive marker and not strictly a marker of the passive. From a typological perspective, it may be instructive here to compare intransitive affixes in other Sino-Tibetan languages. In Rawang, the intransitive $v$ - [ə] prefix can derive passive-like verb forms, whose $\mathrm{S}$ corresponds to the $\mathrm{O}$ of the transitive verb (LaPolla 2001: 288):

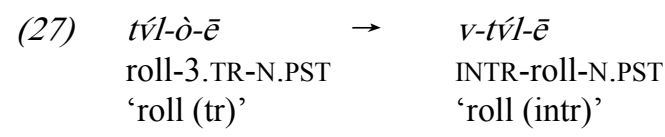

Moreover, according to LaPolla, 'if the single direct argument of the derived intransitive is a plural animate argument, then the meaning is reciprocal'. Here is one of his examples:
(28) àngmaq V-shvt-ē
they INTR-hit/kill- N.PST
'They are fighting.'

The functions of the $v$-prefix in Rawang are reminiscent of those of the proto-Japhug * $y a$ - prefix. ${ }^{9}$ The main difference is that in Japhug (as in all four of the Rgyalrong languages) the reciprocal meaning only appears if the verb stem is reduplicated. 
Interestingly, in Rtau, a language related very closely to the Rgyalrong languages ${ }^{10}$, verb stem reduplication expresses plurality in the subject (S/A) (Huang 1991:29-30), as shown in Table 3.

Table 3: Paradigm of the verb 'go' in Rtau.

\begin{tabular}{lll}
\hline person & singular & plural \\
\hline 1 & $6 O-\eta$ & $60-6 O-\eta$ \\
2 & $6 i-n$ & $60-6 i-n$ \\
3 & 60 & $60-6 \partial$ \\
\hline
\end{tabular}

If we assume that proto-Japhug *ya- had a function similar to the Rawang $v$-, and that the reduplication present in Rtau as a marker of plurality is a survival from proto-Rgyalrongic, the formation of the reciprocal in the modern Rgyalrong languages can be explained: when a *ya- prefixed verb had a plural animate argument, the verb stem was reduplicated, and it developed a reciprocal meaning. After verb stem reduplication ceased to function as a marker of plurality, its presence on * ya- prefixed verbs was reanalysed as a reciprocal marker.

Therefore, although the $a$ - passive prefix and the $a$ - element in reciprocal forms are historically related, they no longer represent the same morpheme in modern Japhug. This is why we argue that the form in $a$ - is a genuine passive and not a vague intransitive or middle.

Finally, it should be noted that many intransitive verbs, such as armbat 'be near' or acqhe 'cough', have a prefixal a- element although no corresponding transitive verb exists. We have no reason to identify such verbs as passives, and can consider the $a$ - element as part of the verb root. However, it should be stressed that no transitive verb has this $a$-element.

\subsection{Prenasalized anticausative}

The prenasalization alternation in Japhug derives an anticausative verb from a transitive one. Only sixteen pairs of verbs present this alternation (Jacques 2008:84-5), and at least one of them ( $\chi$ trr, Table 4) is a loanword from Tibetan (gtor), which shows that this morphological process retained its productivity until recently. ${ }^{11}$

Table 4: Examples of the prenasalized anticausative in Japhug.

transitive meaning $\quad$ intransitive meaning


$16^{\perp} \circ$ Error! Style not defined.

\begin{tabular}{|c|c|c|c|}
\hline ftsi & melt (tr) & $n d z i$ & melt (itr) \\
\hline pryt & break (tr), cut & mbryt & $\begin{array}{l}\text { break (itr), be } \\
\text { cut }\end{array}$ \\
\hline$q r t$ & separate & $N G r t$ & be separated \\
\hline$\chi t r r$ & scatter & Bndrr & be scattered \\
\hline
\end{tabular}

The major difference between the $a$ - passive and the prenasalized anticausative is that the agent is omitted when the $a$-passive form is used, but semantically, the existence of an indefinite external agent is not excluded, whereas in the case of the prenasalized anticausative, no agent is present, and the action is viewed as taking place spontaneously.

$$
\begin{array}{lll}
\text { "wo a-zi } & \text { ra } & \text { nut-mkryur } \\
\text { Oh 1SG.POSS -lady } & \text { PL } & \text { 3PL.POSS-necklace } \\
\text { put-mbrrt” } & \text { tî-nut } & \\
\text { AOR-ANTICAUS:break } & \text { N.PST:say-PL }
\end{array}
$$

'Oh, my lady, your necklace has broken!' they said. (Kunbzang 214)

In this example, the characters uttering this sentence believe that the necklace broke by itself, without an external agent: he therefore uses an anticausative form. If the a-passive a-pryt had been used instead, it could have implied that someone had broken the necklace on purpose.

However, since only a few verbs have a special anticausative form, for the majority of verbs only the $a$ - passive is available to express anticausative meaning. There are phonological constraints on prenasalization: all 16 known examples of transitive verbs to which this process applies have an unvoiced unaspirated stop or affricate in initial position. ${ }^{12}$ Verbs with nasal or fricative initial consonants have no distinct anticausative form.

\section{Antipassive}

Sun (2006: 8) was the first scholar to notice the existence of antipassive forms in a Rgyalrong language, namely Tshobdun (Caodeng). He pointed out that two antipassive prefixes exist in this language: $r E$-, which is used when the patient is non-human, and $s E$-, used with human patients (see Table 5). 
Japhug is very closely related to Tshobdun, and the same distinction applies for the cognate prefixes $r \gamma$ - and $s \gamma$, as can be seen from the following examples: $r \gamma$ - is added to verbs with a prototypical non-human patient, and $s \gamma$ - when the patient is necessarily human.

Table 5: Examples of antipassive derivation in Japhug.

\begin{tabular}{|c|c|c|c|}
\hline basic verb & meaning & derived verb & meaning \\
\hline ndun & read & rr-ndun & read sth. \\
\hline ntsye & sell & rr-ntsye & do business \\
\hline car & search & $r \gamma-6 a r$ & look for sth. \\
\hline fstuun & serve & sr-fstuun & serve $s b$ \\
\hline sndu & & sa-sndu & hit sb. \\
\hline car & search & $S \gamma-G a r$ & look for sb. \\
\hline
\end{tabular}

The resulting verbs are intransitive: they never display any of the signs of verbal transitivity described in part 2 of this paper. The antipassive is not simply a means of changing the case marking of the Agent from Ergative to Absolutive: it involves a change in valency, with the result that the original patient can no longer be expressed. Usually, as in examples (30) and (31), the semantic patient becomes indefinite:
(30)

$$
\text { NEU-wife DET IPFV.EVD-APASS:NONHUM-mend }
$$

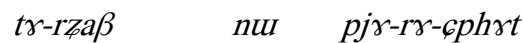

'The wife was mending (clothes).' (The Raven, 19)

(31) tchi tu-tul-ste

$$
\text { what IPFV-2-do_this_way[3] N.PST-be }
$$

$k \gamma$-sr-fstum

INF-APASS:HUM-serve

'How do you serve (your husband and the people from his family)?' (The Frog, 128)

The human/non-human distinction is not always strictly observed. In some examples, a $s \gamma$ - prefixed verb may have a non-human animate

\begin{tabular}{|c|c|c|c|}
\hline (33) & $\begin{array}{l}\text { thut-wxti } \\
\text { AOR-big } \\
k u-s \gamma-n d z a\end{array}$ & $\begin{array}{l}\text { u-juja } \\
\text { 3SG.POSS -following } \\
\quad k u-1\end{array}$ & $\begin{array}{l}\text { tce, } \\
\text { CONJ }\end{array}$ \\
\hline
\end{tabular}
(animal) as its intended patient:

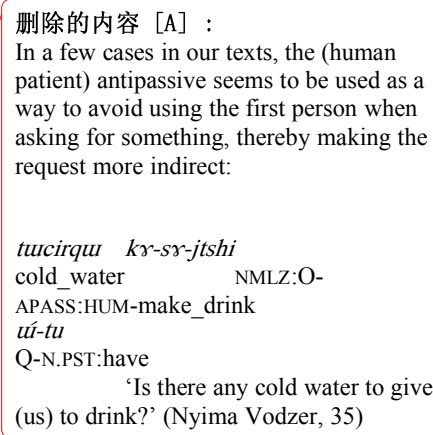


$18^{\perp} \circ$ Error! Style not defined.

\author{
NMZL:S/A-APASS:HUM-eat NMZL:S/A-be DET

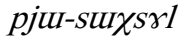 \\ IPFV-realize \\ 'As (the buzzard ${ }_{i}$ ) grows bigger, (the bunting) realizes that $i_{i}$ eats \\ (other birds).' (The Buzzard, 26)
}

In this example, since semantically both the patient and the agent of the verb 'eat' are birds and therefore equals on the Empathy Hierarchy, the antipassive with suppressed human patient prefix $s \gamma$ - is found instead of the expected $r \gamma$.

The Japhug antipassive does not seem to be very productive, and few verb roots are able to take both $r \gamma$ - and $s \gamma$ - prefixes (car "to search" in Table 5 is one example). In both narratives and procedural texts, these forms are quite rare (cf. the text counts in the conclusion).

\title{
6. De-experiencer
}

The de-experiencer prefix $s \gamma$-, homophonous with the antipassive prefix for human patients discussed in the previous section, differs from the other morphological devices presented in this paper. Its basic function is not to decrease valency per se: rather, it derives an intransitive stative verb from an intransitive verb or a transitive verb of perception.

The $\mathrm{S}$ of the derived verb denotes the stimulus of the state or action, and it has the meaning "be liable to cause sb/sth to X", where X is the meaning of the basic verb.

In the case of intransitive verbs, the original $\mathrm{S}$ argument is suppressed and replaced by the stimulus. For transitive perception verbs, the A (corresponding to the experiencer) is suppressed and the original $\mathrm{O}$ (the stimulus) becomes the $\mathrm{S}$ of the derived verb. The examples in Table 6 illustrate this derivation.

Table 6: The de-experiencer prefix with intransitive and transitive verbs.

\begin{tabular}{|c|c|c|c|}
\hline $\begin{array}{l}\text { Basic } \\
\text { verb }\end{array}$ & meaning & Derived verb & meaning \\
\hline ggio & slip (itr.) & sr-pgio & be slippery (of the ground) \\
\hline scit & be happy & $s \gamma-s c i t$ & $\begin{array}{l}\text { be nice (of a situation), be } \\
\text { funny (of a person) }\end{array}$ \\
\hline cke & be burned & sr-cke & be burning (of a boiling kettl \\
\hline
\end{tabular}


e, which burns the hand of anyone touching it)

\begin{tabular}{llll} 
rga & like (itr.) & $s \gamma$-rga & be nice \\
\hline mto & see & $s \gamma$-mto & be easy to see \\
mtshrm & hear & $s \gamma$-mtshrm & be easy to hear
\end{tabular}

Since the deleted argument is always the experiencer (whether the verb is transitive or intransitive), we label this prefix "de-experiencer".13 Although in the case of intransitive verbs there is no decrease in valency, the addition of this prefix is nonetheless a demotion in the sense that a stimulus is lower than an experiencer in terms of agentivity (for instance, humans are less likely to be stimuli).

\section{Lability}

While transitive and intransitive verbs can be easily distinguished on formal grounds (see section 2), a small class of verbs can be either transitive or intransitive. Table 7 presents a list of the labile verbs identified in Japhug up to this point.

Table 7: Labile verbs in Japhug.

\begin{tabular}{|c|c|c|c|}
\hline Japhug & meaning & Japhug & meaning \\
\hline srgo & listen & гґлғовлні & crush \\
\hline пrтрпо & look & yndzuur & grind \\
\hline rпu & fry & nukhaja & resist \\
\hline murku & steal & sulasrdr $\beta$ & $\begin{array}{l}\text { kick (of an } \\
\text { animal) }\end{array}$ \\
\hline rpu & bump & suqartsut & kick \\
\hline$f_{6 i} i$ & forge & пшъятппяn & envy \\
\hline clu & plough & питьггри & $\begin{array}{l}\text { ride (on } \\
\text { horseback) }\end{array}$ \\
\hline $\operatorname{ta} b$ & weave & & \\
\hline
\end{tabular}

For instance, the verb rpu 'bump into' can appear both with and without the $1 \mathrm{sg} / 2 \mathrm{sg}$ Aorist $-t$ suffix, cf. the following examples:
(34) $u$ u-tab
$k \gamma-r p u-a$
3SG.POSS-up
AOR:EAST-bump_into-1SG 
$20^{\perp} \circ$ Error! Style not defined.

'I bumped into him.'

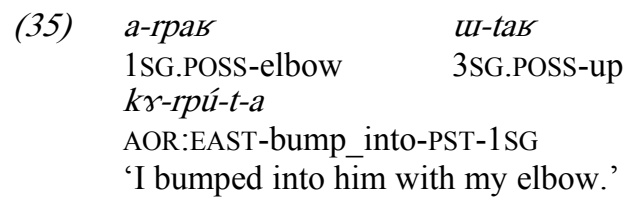

In sentence (35), the verb bears a transitive $-t$ suffix, and the patient of the clause, 'my elbow', is overt (the person bumped into is indicated with an oblique case). In sentence (35), in contrast, the body part involved is not expressed, and the verb lacks the transitive marker; here $u$-tas 'on him' is syntactically not the object of the verb but an adjunct. The lability observed in these two examples is agent-preserving: the agent of the transitive verb, and not the patient, remains when the verb is used intransitively. ${ }^{14} \mathrm{We}$ will label the S/A argument of labile verbs as the 'subject'.

Since nouns in Japhug take ergative marking, this implies that the subject is marked with the ergative case when the verb is transitive, and has absolutive marking when the verb is intransitive. Consider the following examples, involving the labile verb numbrrpu 'ride'.

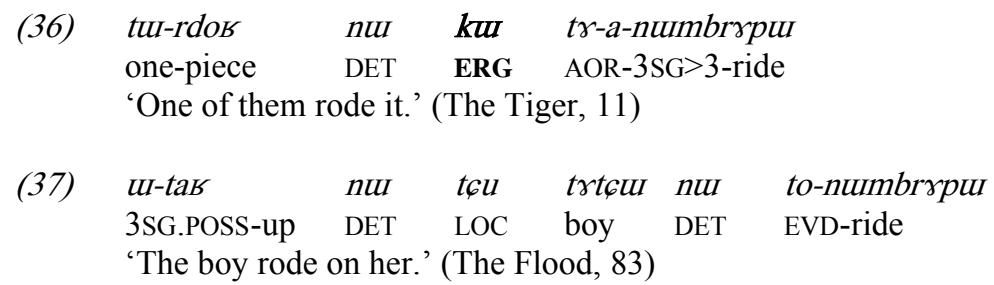

In example (36), the agent is marked with the ergative. The patient is not overt, but the transitive $a$ - prefix on the verb and the presence of ergative case indicate that the verb is to be interpreted as transitive: the patient is definite (it refers to a tiger mistakenly stolen by three thieves).

In example (37), the subject 'the boy' does not bear ergative case, and the verb must be interpreted as intransitive (though in this example the evidential verbal form itself is ambiguous as regards transitivity). As in examples (34) and (35), ut-tas 'on her' is an adjunct, and does not participate in the verb's argument structure. Similar examples could be found for all verbs in Table 7. 
These verbs belong to two distinct semantic categories: perception/feeling ('listen to', 'look at', 'envy') and concrete action ('grind', 'bump into', 'forge' etc). Interestingly, no 'verbs of ingestion' such as 'eat' are found in this list. Næss (2007: 126) claims that "For most languages for which I have been able to find data, it is the case that if they allow indefinite object deletion with any verb, they will allow it with "eat", but the verbs $n d z a$ 'eat' and tshi 'drink' are strictly transitive in Japhug; intransitive verbs of ingestion do exist, such as rundzrtshi 'have lunch', but they are not related to their transitive equivalents by means of lability.

Interestingly, none of the labile verb pairs discovered so far seems to show an unpredictable change in meaning, although these are very common cross-linguistically, as for instance with English 'drink', which as an intransitive principally bears the meaning 'drink alcohol'.

No examples of patient-preserving lability have so far been found in Japhug.

\section{Incorporation}

The last argument-demotion device in Japhug is verbal incorporation. It is not widespread but restricted to a few verbs, though the fact that some examples involve recent Chinese and Tibetan loanwords shows that the process is still potentially productive.

Incorporated nouns involve objects (see 'timber' and 'money' in the following table), subjects of intransitive verbs ('horse') and a few adjuncts ('back'), but never the agent of a transitive verb. The incorporated noun root appears before the verb root, following the normal strict verb-final order of the language. Some examples are given in Table 8.

Table 8: Examples of incorporated nouns in Japhug

\begin{tabular}{|c|c|c|c|}
\hline noun & verb & incorporation & meaning \\
\hline mbro 'horse' & rfuy 'run' it. & nu-mbrr-rfuy & gallop it. \\
\hline qhu 'back' & $r u$ 'look' it. & $n \gamma-q h a-r u$ & $\begin{array}{l}\text { turn around, } \\
\text { look back it. }\end{array}$ \\
\hline$s i$ 'timber' & phut 'chop' tr. & yu-su-phut & fell trees it. \\
\hline $\begin{array}{l}\text { pcawtsul 'money'15 } \\
\text { qhu 'back' }\end{array}$ & $\begin{array}{l}\text { fSOB 'earn' tr. } \\
\text { gga 'wear' tr. }\end{array}$ & 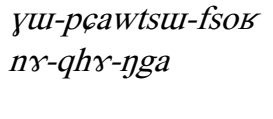 & $\begin{array}{l}\text { earn money it. } \\
\text { wear on the } \\
\text { back tr. }\end{array}$ \\
\hline
\end{tabular}




\section{$22^{\perp} \circ$ Error! Style not defined.}

Morphological marking on the incorporated noun is extensive. Firstly, the incorporated noun appears between a derivational prefix (nu-, nr- or $\mathrm{yul}^{-}$) and the verb root. Secondly, if the noun ends in an open syllable, the vowel usually undergoes one of a set of regular changes also found in compound nouns, giving a form we call status constructus:

$$
\begin{aligned}
& -o \rightarrow-\gamma /-a \\
& -u \rightarrow-\gamma /-a \\
& -i \rightarrow-u t
\end{aligned}
$$

When the verb incorporates the patient of the original verb (see 'fell trees' and 'earn money' above), the incorporated verb becomes intransitive: this is a case of saturating incorporation. When, however, the incorporated noun is an adjunct ('wear on the back'), it does not affect the valency of the verb.

Most incorporated objects can appear with the same verb as free objects, but there are a few frozen incorporated objects which are no longer felt as such. Sometimes both forms appear next to one another in the same story, as can be seen in examples (38) and (39).

$\begin{array}{lllll}\text { tasa ju-ku-ce } & \text { tce, } & \text { nut } & \text { tcu } & \\ \text { Lhasa IPFV-GENR:S/O-go } & \text { CONJ } & \text { DEM } & \text { CONJ } \\ \text { pcawtsur } k \gamma \text {-fsor } & \text { nut-mbat } & & \\ \text { money INF-earn } & \text { CONST-easy } & & \end{array}$

'If one goes to Lhasa, money is easy to earn there.' (Lobzang, 22)

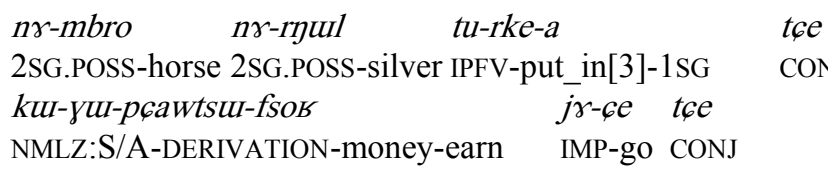

'I will prepare a horse and some silver for you: go to earn money.' (Lobzang, 17)

In (39), pcawtsu 'money' is incorporated, whereas in (38) it appears as a free object. As these examples show, the semantic difference between free and incorporated object is minimal here; in both cases the object is indefinite.

The decrease in valency caused by incorporation shows some similarity with the effects of antipassivization. The incorporated object can never be definite, and there are strong restrictions on which objects can be incorporated. The activity expressed by the verb must be, as Mithun (1984:848) puts it, "recognized sufficiently often to be considered name- 
worthy in its own right”. For instance, the verb mtshi 'lead' can only appear with two incorporated objects, jla 'yak/cow hybrid' and mbro 'horse', never with any other animal.

\section{Conclusion}

In Japhug, covert arguments of transitive verbs are generally interpreted as definite, though a few exceptions are treated in this article. Therefore, indefinite arguments, in particular unknown or generic ones, must be demoted. Patients can be suppressed by means of four distinct constructions - generic, antipassive, lability and incorporation; while only two possibilities exist for the suppression of agents, namely the generic and passive constructions. Japhug has a wide range of very specialized argument demotion devices, including passive, reciprocal, de-experiencer and reflexive (not mentioned in the present article; see Jacques 2010b).

We have already outlined some important differences in the use of these forms, but additional insight may be gained from text counts. The distribution we found in a corpus of eight narrative texts, and another comprising two procedural texts, is presented in Table 9. ${ }^{16}$

Table 9: Text counts of argument demotion

\begin{tabular}{|l|l|l|l|l|}
\hline & \multicolumn{2}{|l|}{ narrative } & \multicolumn{2}{l|}{ procedural text } \\
\hline inverse (excluding generic) & 35 & $3.1 \%$ & 0 & $0 \%$ \\
\hline A-generic & 2 & $\mathbf{0 . 2} \%$ & 215 & $\mathbf{4 9 . 2} \%$ \\
\hline O-generic & 0 & $0 \%$ & 0 & $0 \%$ \\
\hline S-generic & 4 & $0.4 \%$ & 2 & $0.5 \%$ \\
\hline labile verb as transitive & 2 & $0.2 \%$ & 0 & $0 \%$ \\
\hline other transitive & 564 & $\mathbf{5 1 . 1} \%$ & 46 & $\mathbf{1 0 . 5} \%$ \\
\hline \hline antipassive & 3 & $0.3 \%$ & 0 & $0 \%$ \\
\hline passive & 8 & $0.7 \%$ & 6 & $1.4 \%$ \\
\hline labile verb as intransitive & 27 & $2.4 \%$ & 0 & $0 \%$ \\
\hline incorporation & 1 & $0.1 \%$ & 0 & $0 \%$ \\
\hline other intransitive & 459 & $41.4 \%$ & 168 & $38.4 \%$ \\
\hline
\end{tabular}

In both narrative and procedural texts, $\mathrm{S} / \mathrm{O}$ generic forms, antipassive and incorporation are all barely attested. Passive verb forms are less rare, but the majority of examples involve one of just three common verbs: $a$ 


\section{$24^{\perp} \circ$ Error! Style not defined.}

$r k u$ 'be placed in', a-ta 'be placed' and $a-\beta z u$ 'become'. In comparison with such languages as Kutenai (Dryer 1994:75), where passive forms constitute up to $27 \%$ of all semantically transitive clauses, it is clear that the Japhug passive is very restricted in usage.

The major difference between the two categories of texts lies in the generic use of the inverse. Almost unattested in narratives, it is by far the most common form in procedural texts. Of all five argument-demoting mechanisms, the generic is the only one which is fully productive.

It is instructive to evaluate to what extent the syntactic properties of the four patient-demoting constructions in Japhug are common for such constructions cross-linguistically. Bickel et al. (2007:18) propose a set of ten properties commonly associated with antipassive (A), incorporation (I) and optional agreement (OA). The properties of the Japhug constructions are given in Table $10 .{ }^{17}$

Table 10: Typological comparison of syntactic properties of Patient-Demoting constructions.

\begin{tabular}{llll|l|lll}
\hline & $\mathrm{A}$ & $\mathrm{I}$ & $\mathrm{OA}$ & $\mathrm{G}(\mathrm{J})$ & $\mathrm{A}(\mathrm{J})$ & $\mathrm{L}(\mathrm{J})$ & $\mathrm{I}(\mathrm{J})$ \\
\hline O is adjacent to verb & $\mathrm{n}$ & $\mathrm{y}$ & $\mathrm{n}$ & $\mathrm{n}$ & $\mathrm{n}$ & $\mathrm{n}$ & $\mathrm{y}$ \\
O and verb in one word & $\mathrm{n}$ & $\mathrm{y}$ & $\mathrm{n}$ & $\mathrm{n}$ & $\mathrm{n}$ & $\mathrm{n}$ & $\mathrm{y}$ \\
O is obligatory & $\mathrm{n}$ & $\mathrm{y}$ & $\mathrm{n}$ & $\mathrm{n}$ & $\mathrm{n}$ & $\mathrm{n}$ & $\mathrm{y}$ \\
O is deleted & $?$ & $\mathrm{n}$ & $\mathrm{n}$ & $\mathrm{y}$ & $\mathrm{y}$ & $\mathrm{y}$ & $\mathrm{n}$ \\
O is a fully-fledged NP & $\mathrm{y}$ & $?$ & $\mathrm{y}$ & $\mathrm{n} / \mathrm{a}$ & $\mathrm{n} / \mathrm{a}$ & $\mathrm{n} / \mathrm{a}$ & $\mathrm{n} / \mathrm{a}$ \\
Relativization on O & $\mathrm{y}$ & $?$ & $\mathrm{y}$ & $\mathrm{n} / \mathrm{a}$ & $\mathrm{n}$ & $\mathrm{n}$ & $\mathrm{n}$ \\
Regular O-case on O & $\mathrm{n}$ & $\mathrm{n}$ & $\mathrm{y}$ & $\mathrm{n} / \mathrm{a}$ & $\mathrm{n} / \mathrm{a}$ & $\mathrm{n} / \mathrm{a}$ & $\mathrm{n} / \mathrm{a}$ \\
Transitive A-case on A & $\mathrm{n}$ & $\mathrm{n}$ & $\mathrm{y}$ & $\mathrm{y}$ & $\mathrm{n}$ & $\mathrm{n}$ & $\mathrm{n}$ \\
Suspended O-agreement & $\mathrm{y}$ & $\mathrm{y}$ & $\mathrm{y}$ & $\mathrm{y}$ & $\mathrm{y}$ & $\mathrm{y}$ & $\mathrm{y}$ \\
Generic O or O with & $\mathrm{n}$ & $\mathrm{y}$ & $?$ & $\mathrm{y}$ & $\mathrm{eithe}$ & $\mathrm{y}$ & $\mathrm{y}$ \\
unknown cardinality & & & & & $\mathrm{r}$ & & \\
\hline
\end{tabular}

Incorporation aside, the three other constructions differ very little as far as these ten properties are concerned.

As is the case for many antipassive constructions cross-linguistically, in the Japhug Antipassive the demoted patient cannot be retained in the clause concerned, even in an oblique case. The Japhug Passive behaves analogously, as its use rules out the specification of an Agent in the clause.

As we have seen in the present article, the Japhug Passive and Antipassive have a variety of functions, but they do not serve to topicalize 
the Patient/Agent (word order, elision of the argument and inverse marking are used instead) or make the Patient/Agent argument accessible to relativization (as $\mathrm{S}, \mathrm{A}$ and $\mathrm{O}$ can all be relativized).

They do not share the whole set of parameters which are commonly associated with the terms 'passive' and 'antipassive', but nevertheless these terms seem to be appropriate labels to describe the behaviour of the affixes discussed here. Whether these properties are cross-linguistically common or rare, and whether some of them are somehow correlated with ergative alignment, are questions which lie beyond the scope of this article.

\section{References}

Bickel, Balthasar, Martin Gaenzle, Arjun Rai, Prem Dhoj Rai, Shree Kumar Rai, Vishnu S. Rai and Narayan P. Sharma

2007 "Two ways of suspending object agreement in Puma: between incorporation, antipassivization and optional agreement." Himalayan Linguistics 7: 1-19.

DeLancey, Scott

1981 "The category of direction in Tibeto-Burman." Linguistics of the Tibeto-Burman Area 6(1): 83-101.

Dryer, Matthew S.

1994 "The discourse function of the Kutenai inverse." In Voice and Inversion, T. Givon (ed.), 65-99. Amsterdam/Philadelphia: Benjamins.

Haspelmath, Martin

2005 "Argument marking in ditransitive alignment types." Linguistic Discovery 3(1): 1-21

Hopper, Paul J. and Sandra S. Thompson

1980 “Transitivity in grammar and discourse." Language, 56(2): 251-299.

Jacques, Guillaume

2004 Phonologie et morphologie du Japhug (rgyalrong), thèse de doctorat, université Paris VII-Denis Diderot.

2008 嘉䋐語研究 Jiarongyu yanjiu [Study on the Rgyalrong language]. Beijing: Minzu chubanshe.

2010a "The inverse in Japhug Rgyalrong." Language and Linguistics, 11(1): 127-157.

$2010 \mathrm{~b} \quad$ "The origin of the reflexive prefix in Rgyalrong languages." Bulletin of the School of Oriental and African Studies, 73(2): 261-268.

Jacques, Guillaume and Chenzhen 


\section{$26^{\perp} \circ$ Error! Style not defined.}

“茶堡話的不及物前経及相關問題 Chabaohua de bujiwu qianzhui ji xiangguan wenti [The intransitive prefix in Japhug and related problems]." Language and Linguistics, 8(4): 883-912.

Jacques, Guillaume and Alexis Michaud

2011 The reconstruction of Proto-Naic: a preliminary study of the historical phonology of highly eroded Sino-Tibetan languages, Diachronica, 28.4.

Keenan, Edward L. and Dryer, Matthew S.

2007 "Passive in the World's Languages." In Clause Structure, Language Typology and Syntactic Description, Vol. 1, Timothy Shopen (ed.), 325-361. Second Edition. Cambridge University.

LaPolla, Randy

2001 "Valency-changing derivations in Dulong/Rawang." In Changing valency: Case studies in transitivity, R.M.W. Dixon and A.Y. Aikhenvald (eds.), 282-311. Cambridge: Cambridge University Press.

2008 "Transitivity and transitivity alternations in Rawang and Qiang." In Proceedings of the Workshop on Tibeto-Burman Languages of Sichuan, 239-248. Academia Sinica, Institute of Linguistics, November 21-22.

Mithun, Marianne

1984 "The evolution of noun incorporation." Language 60:847-94.

1999 The Languages of Native North America. Cambridge Language Surveys. Cambridge: Cambridge University Press.

Næss, Åshild

2007 Prototypical Transitivity. Amsterdam/Philadelphia: John Benjamins.

Sun, Jackson T.-S.

2000 "Parallelisms in the verb morphology of Sidaba rGyalrong and Lavrung in rGyalrongic." Language and Linguistics 1(1). 161-190.

2003 "Caodeng rGyalrong." In Sino-Tibetan Languages, Graham Thurgood and Randy J. LaPolla (eds.), 490-502. London: Routledge.

2005 "Linguistic Coding of Generic Human Arguments in rGyalrongic Languages," 11th Himalayan Languages Symposium, 6-9 December, 2005, Chulalongkorn University, Bangkok, Thailand.

2006 “嘉戎語動詞的派生形態 Jiarongyu dongci de paisheng xingtai [Derivational morphology in the Rgyalrong verb]." Minzu yuwen 4:3-14.

Sun, Jackson T.-S. and Shidanluo

2002 草登嘉䋐語與“認同等第”相關的語法現象 Caodenghua yu « rento ng dengdi » xiangguan de yufa xianxiang [Caodeng Rgyalrong and grammatical phenomena related to the Empathy Hierarchy],

Zúñiga, Fernando Language and Linguistics, 3.1:79-99. 
Deixis and Alignment: Inverse Systems in Indigenous Languages of the Americas. Amsterdam/Philadelphia: Benjamins.

\section{Notes}

1. I collected the data presented in this article in a series of field trips to China undertaken from 2002 onwards. My main informant for this language was Chenzhen. I wish to thank Peter Austin, Gilles Authier, William Croft, Henriette Daudey, Katharina Haude, Steven Kaye and an anonymous reviewer for their insightful comments, corrections and discussions. This article was completed during my stay as a visiting scholar at the Research Centre for Linguistic Typology, LaTrobe University: I am grateful to Randy LaPolla for making this visit possible. The glosses generally follow the Leipzig Glossing Rules, except for the following: ADV adverbializer, ANTICAUS anticausative, APASS antipassive, CIS cislocative, CONJ conjuction, CONST constative, DOWNSTR downstream, EVD evidential, GENR generic, HUM human,INTSV intensive, INV inverse, NEU neuter (indefinite possession), NONHUM nonhuman, N.PST non-past, STAT stative, TRANS translocative, UPSTR upstream.

2. The Rgyalrong languages are themselves a sub-branch of the Qiangic branch of Sino-Tibetan, which comprises the extinct Tangut language, as well as Qiang, Pumi, Muya, Queyu, Zhaba, Lavrung and Rtau. Guiqiong, Shixing, Namuyi and Ersu, generally thought to belong to this branch, should probably be classified differently (Jacques and Michaud 2011).

3. In the Rgyalrong languages, verbs can have up to three or four distinct stems (Sun 2000). Stem 3 is used in Non-past, Imperfective, Irrealis and Imperative forms with a singular agent and a third person patient (Jacques 2008:246-7).

4. This clitic is probably borrowed from the Tibetan ergative marker gyis.

5. The external argument is not overt in example (10); if present, it would take the form $n \gamma-c k i$ or $n \gamma-p h e$.

6. In example (16), direct forms would also be grammatical. The inverse appears here for pragmatic reasons, because the patient (the two brothers) is more topical than the agent (the unnamed people who perform their execution). See Jacques (2010a) for a more detailed discussion of this phenomenon.

7. This verb has primative/secundative alignment (Haspelmath 2005). The recipient is treated as the $\mathrm{O}$, and the theme is not encoded on the verb. Other ditransitive Japhug verbs, however, have indirective alignment, as mentioned above.

8. On the origin of this prefix, see Jacques (2010b).

9. This was suggested to me by an anonymous reviewer of the journal 'Language and Linguistics', whom I wish to thank again for insightful 
$28^{\perp} \circ$ Error! Style not defined.

comments

10. Sun (2000) argues convincingly that Rtau and Lavrung are the closest relatives of Rgyalrong within Qiangic. He calls the sub-branch including the Rgyalrong languages, the Lavrung languages and Rtau 'Rgyalrongic', a term which we also adopt here.

11. However, the phonological correspondence -or : $-\gamma r$ shows that it belongs to the earliest layer of Tibetan loanwords (Jacques 2008:136-146).

12. We use 'initial' here in the sense defined in Jacques (2004: 12-73).

13. This terminology was suggested by Peter Austin. The counterpart of the deexperiencer prefix among transitivizing affixes is the estimative prefix $n \gamma$, which derives a transitive verb from an intransitive one whose A corresponds to the experiencer and whose $\mathrm{O}$ corresponds to the stimulus (the $\mathrm{S}$ of the basic verb), for instance mpcrr "be beautiful" > nrmpcrr "consider to be beautiful".

14. This phenomenon is described by Næss (2007: 125) as 'Indefinite Object deletion'.

15. The word pcawtsu 'paper money' comes from the colloquial Chinese piaozi 票子.

16. No examples of the de-experiencer $s \gamma$ - with a transitive verb were found in this part of the corpus.

17. The abbreviations $G(J), A(J), L(J)$ and $I(J)$ correspond to the Generic, Antipassive, Lability and Incorporation constructions of Japhug. The symbols $\mathrm{y}, \mathrm{n}, \mathrm{n} / \mathrm{a}$ and ? stand for 'yes', 'no', 'not applicable' and 'true in some languages'. 